\title{
NOVA ESPÉCIE DE BAHITA OMAN (HOMOPTERA, CICADELLIDAE, DELTOCEPHALINAE) ${ }^{1}$
}

\author{
Keti Maria Rocha Zanol ${ }^{2}$
}

\begin{abstract}
A New Species of Bahita OMan (Homoptera, Cicadellidae, DeltoCEPHALINAE). Bahita maracana sp.n., from Brazil, is described.

KEY WORDS. Homoptera, Cicadellidae, Deltocephalinae, Bahita
\end{abstract}

O material estudado pertence às seguintes Instituições: Instituto Nacional de Pesquisas da Amazônia, Manaus (INPA) e Coleção de Entomologia Pe J.S. Moure, Departamento de Zoologia, Universidade Federal do Paraná, Curitiba (DZUP).

\section{Bahita maracana sp.n.}

Figs 1-8

Holótipo macho. Cabeça de comprimento uniforme. Sutura coronal ultrapassando a metade do comprimento da coroa. Margem anterior estriada. Região frontal voltada para cima; superfície lisa com leves estrias transversas. Região discal lisa com leves estrias longitudinais. Ocelos situados na margem anterior. Área ocelo-ocular menor que o diâmetro dos ocelos. Coloração marfim; margem anterior, com uma faixa transversa, junto a região frontal, entre as suturas frontoclipeais e outras duas, no disco, de cada lado da sutura coronal, marrons. Região discal amarelo-ouro. Face marrom; frontoclípeo com arcos laterais e duas faixas transversas, uma entre os ocelos e outra acima destes, amarelos. Sutura frontoclipeal estendendo-se além dos ocelos. Anteclípeo de lados paralelos, levemente túmido. Genas com reentrância abaixo dos olhos.

Pronoto mais estreito que a cabeça; superfície lisa; coloração amarelada irrorado de marrom. Escutelo marfim; triângulos basais e uma faixa longitudinal, mediana, marrom-claros contornados de marrom.

Tégminas com duas células anteapicais; a externa alcançando a célula apical. Veia transversa s ausente. Clavo com veia extranumerária entre $1 \mathrm{~A}$ e a sutura e duas entre as veias anais. Apêndice desenvolvido. Coloração marrom-clara, semitransparente. Venação marrom. Clavo com três manchas, de contorno irregular, marfim: uma entre as Anais e duas entre 1A e a sutura. Manchas longitudinais nas células, ápice e junto a margem costal, marrons. Células com áreas circulares esbranquiçadas.

1) Contribuição número 968 do Departamento de Zoologia, Universidade Federal do Paraná.

2) Departamento de Zoologia, Universidade Federal do Paraná. Caixa Postal 19020, 81531-990 Curitiba, Paraná, Brasil. Bolsista CNPq. 

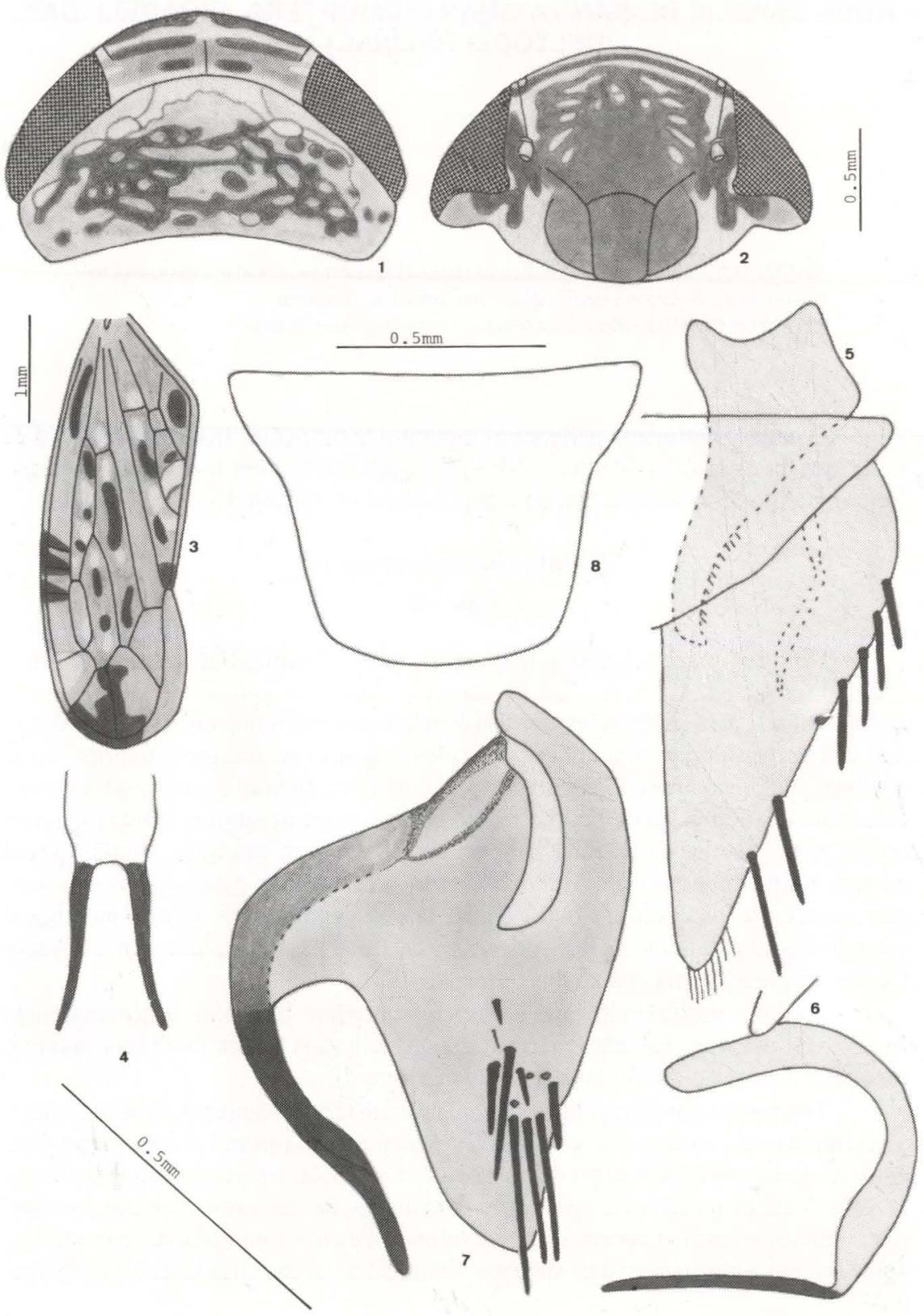

Figs 1-8. Bahita maracana sp.n., holótipo macho. (1) Cabeça e pronoto, dorsal; (2) face; (3) tégmina; (4) ápice do edeago, ventral; (5) valva genital, placa subgenital e estilo; (6) edeago, lateral; (7) pigóforo, lateral; (8) VII esternito (parátipo). 
Genitália. Pigóforo com um par de apêndices sinuosos, mais longos que o pigóforo. Valva triangular. Placa subgenital triangular; margem sinuosa; macrocerdas unisseriadas. Estilos digitiformes; ápice curvo para fora. Edeago com um par de apêndices apicais, sinuosos e divergentes; terço apical, em vista lateral, alargado.

Fêmea. Coloração pouco mais escura que do macho. Tégminas com veia transversa s presente. Sétimo esternito, quadrangular; margens laterais estreitandose para o ápice; margens látero-posteriores arredondadas. Superfície com uma leve carena mediana, na metade apical.

Medidas (mm). Macho/fêmea. Comprimento total 6,30/6,50; largura da cabeça 2,20/2,40; largura do pronoto 2,00/2,20.

Material examinado. Holótipo macho. BRASIL, Roraima: Ilha de Maracá (Rio Uraricoera, armadilha suspensa), 21-30-XI-1987, J.A. Rafael e equipe leg. (INPA). Parátipos: ibidem, 5 machos, 1 fêmea (DZUP); ibidem, 02-13-V-1987, 4 machos (INPA).

Variação intraespecífica. Em alguns casos a veia transversa s pode ocorrer apenas numa das tégminas. Pode ocorrer uma ou três veias extranumerárias entre as veias Anais. A veia extranumerária entre $1 \mathrm{~A}$ e a sutura pode ser bifurcada.

Comentários. Esta espécie é muito parecida com B. infuscata (Osborn) mas os apêndices do pigóforo são sinuosos, o edeago é menor e os apêndices não tão divergentes. O sétimo esternito da fêmea apresenta as margens laterais estreitadas e a superfície com leve carena, somente na metade apical.

Etimologia. O nome da espécie é alusiva a Ilha de Maracá, Roraima.

\section{REFERÊNCIAS BIBLIOGRÁFICAS}

LiNNAVUORI, R. 1959. Revision of the Neotropical Deltocephalinae and some related subfamilies (Homoptera). Ann. zool. Soc. Bot. fennicae Vanamo 29 (1): $1-370$.

LINNAVUORI, R. \& D.M. DeLONG. 1978a. Neotropical leafhoppers of the "Bahita" group (Homoptera: Cicadellidae: Deltocephalinae). A contribution to the taxonomy. Brenesia 14-15: 109-169.

1978b. Some new or little known Neotropical Deltocephalinae (Homoptera: Cicadellidae). Brenesia 14-15: 227-247.

Recebido em 26.IX.1996; aceito em 09.IV.1997. 